\title{
Applying Artificial Neural Network to Optimize the Performance of the Compressor Station: A Case Study
}

\author{
Ivan ĐURAČIĆ*, Marinko STOJKOV, Tomislav ŠARIĆ, Tomislav ALINJAK, Krešimir CRNOGORAC
}

\begin{abstract}
This paper presents the implementation of a reprogrammable PLC system as a monitoring control tool in the actual operating environment of a compressor station. A neural network is used to recognize the temperature pattern and to predict the temperature on the compressor station. A cooling system is installed for the optimization purpose of the observed system. The research was conducted in three stages in real working conditions within the production hall. The difference in temperatures with and without the added cooling system is shown. There are gaps in this research that represent opportunities for future development, therefore recommendations for further research are given.
\end{abstract}

Keywords: compressor; fan; loT; neural network; optimization; preventive maintenance

\section{INTRODUCTION}

One of the important factors that affect the lifespan of electrical equipment is certainly temperature generated inside and outside of the observed device. The term "device" refers to any type of engine, propulsion engine, the composition of interconnected machines in a facility or another device. In this paper, we analyze the operating systems that do not have a built-in cooling system.

The impact of heat on the engine's lifespan is huge. A Swedish physicist Svante August Arrhenius (1859 - 1927), often referred to as the founder of physical chemistry as a science, came to the realization that at different temperatures the rate of a chemical reaction depends on temperature [1].

The use of artificial intelligence in previous research shows a great potential for various purposes in modern production technologies [2-8]. T. Chaudhuri et al. [9] used artificial neural network to reduce power consumption in air conditioners and mechanical ventilation systems. Their proposed model shows an energy-saving potential of $36,5 \%$. In a paper written by J. Reynolds et al., [10] the neural network has the task of predicting energy demand in relation to the possibility of supply from renewable energy sources. This strategy resulted in a profit increase of $52,92 \%$, while $\mathrm{CO}_{2}$ emissions were reduced by $3,75 \%$. A. Afram et al., in their study [11] reduced the operating costs of residential HVAC systems between $6 \%$ and $73 \%$ depending on the time of year. Their algorithm gives between $6 \%$ and $59 \%$ better predictive results in relation to the default algorithm of MATLAB ${ }^{\circledR}$ software package. A. Noroozi et al., [12] inspired by the neural network, genetic algorithm, and particle swarm successfully implemented an algorithm with an adaptive learning approach when planning problems with machines in serial production.

There are various programmable logic controllers (PLCs) on the market that have the tasks of managing and monitoring industrial production systems [13-15]. E. R. Alphonsus et al., in their review, showed that the use of simple or extremely complicated PLCs has its disadvantages, but they are far smaller than the advantages of such devices [13]. Since the industry is progressing on a daily basis and the use of artificial intelligence in the industry is our present and not a far future, in this paper we propose a new kind of PLC, which serves as a controlmonitoring unit [16]. Predictive maintenance methods have been gaining increasing attention in recent years $[17$, 18]. However, the use of techniques for optimization and decision-making regarding the maintenance of multicomponent systems is still an under-explored area.

According to [17], the authors aim at optimal planning in the maintenance of multi-component systems based on prognostic/predictive information with consideration of different dependencies on system components. They presented dynamic predictions policy with system maintenance while minimizing the mid-term maintenance costs per unit of time.

The purpose of this paper is to use a neural network for optimization on the compressor station operation mode by adding a cooling fan to the system. Optimization is done in order to extend the compressor's lifespan, reduce the power consumption with the added fan and for preventive maintenance of the system. Predictive methods are analyzed and used for the purpose of accident prevention of the observed production system.

The next section presents a description of the observed system. The device with which measurements were carried out was also presented. An analysis of results is presented in section three while chapter four shows system optimization by using a neural network. In the last chapter conclusion and proposal for future work are given.

\section{DESCRIPTION OF THE OBSERVED SYSTEM}

The research was conducted at the compressor station at the enterprise "Đuro Đaković Aparati d.o.o" in SlavonskiBrod. The measurements were carried out through three stages in the actual operating conditions of the compressor station. In the first stage, the temperature on the compressor station was measured under different load degrees in 10 working days. The second stage included measurements lasting a month where the temperature was measured at the most critical place on the compressor which is under pressure at about 300 bars in the fourth degree of operation. The room ambient temperature is measured and considered. In the third stage, the final measurement was performed and the temperature 
of the compressor was measured when the compressor was cooled by a $0,12 \mathrm{~kW}$ single-phase fan motor.

A monitored compressor is part of a compressed air production plant used to drive $\mathrm{CNC}$ machines, hand grinders, and pressure testing on bottles with compressed air. The compressor pressurizes the air for filling bottles for supply purposes to about 200 bars. The compressed air in the bottle is reduced further to $6-7$ bars and distributed to the consumption points.

Fig. 1 gives an overview of the compressor station where:

1. Measuring device (Telematiks),

2. Electromotor on the compressor station,

3. A bottle filled with compressed air.

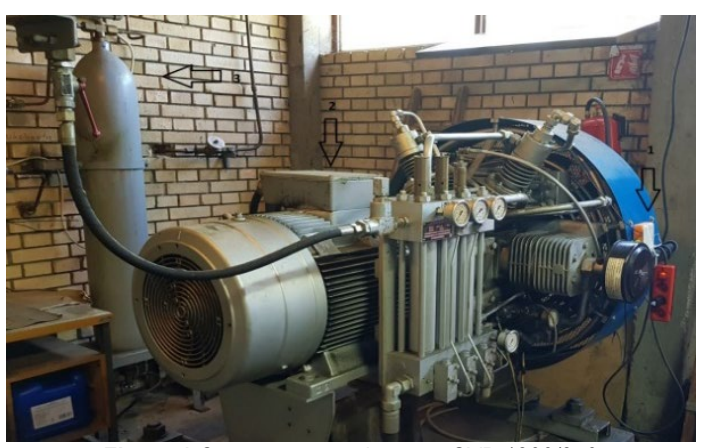

Figure 1 Compressor station type SVB 1300/359

The observed compressor is type SVB 1300/359 with a power of $32 \mathrm{~kW}, 14,5$ liters of oil filling and a maximum speed of $1470 \mathrm{rpm}$ and cooled by the ambient room air temperature. The electromotor of the compressor station is $1570 \mathrm{~mm}$ long, $1050 \mathrm{~mm}$ wide, $1085 \mathrm{~mm}$ high, and $690 \mathrm{~kg}$ in weight. The compressor has 4 degrees of operation (4 cylinders, 4 plungers), where degree 1 operates at about 50 bar and the degree 4 to a maximum of 350 bar. A load of compressed air consumption depends on how many devices are included in the system. Usually, there are two $\mathrm{CNC}$ machines that operate 16 hours per day.

A device called Telematiks [16], patented in 2016, was used for the measurement. Although Telematiks has been presented and patented for other purposes, its application is of a wider range. Since the device is fully reprogrammable (besides various types of measurements), it is possible to use it to remotely control individual systems or for automatic control using any type of artificial intelligence. Telematiks via the IoT (Internet-of-Things) platform provides access to the measured data to the enduser (operator) of the system in real-time. Fig. 2 shows the measuring probe (1) placed at the most critical location of the compressor.

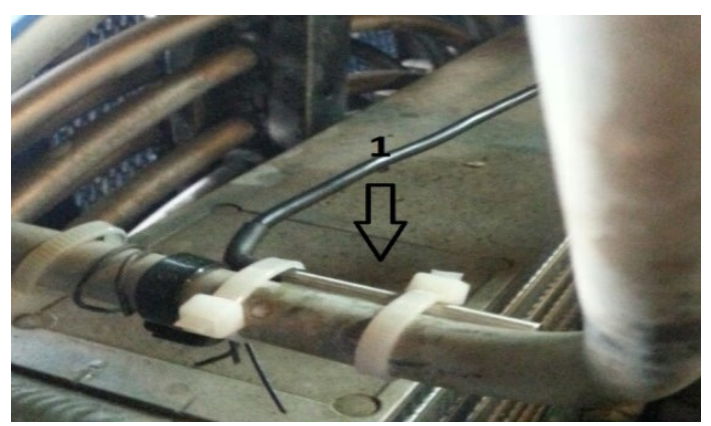

Figure 2 Measuring probe placed at the most critical place of the compressor
If the compressor station stops working due to high temperatures on the compressor, it is to be expected that such a repair will take about 10 days. One hour of stagnation on the compressor station costs 18 euro + VAT per CNC. It follows that 1 day of stagnation costs 555 euro + VAT (data obtained from the director of the company). If $\mathrm{CNC}$ machines have not made a significant supply so that other machines can continue to operate, the cost of stagnation increases significantly. It should be noted that the compressor station has a supply of compressed air for about 24 hours, which allows the smooth operation of the machines due to minor failures.

\section{ANALYSIS OF RESULTS}

In the first stage of the research, compressor temperatures under different load degrees were measured. Temperatures were measured when the compressor was in the first $\left(T_{1}\right)$ and fourth $\left(T_{2}\right)$ operating degree. From the results given in Tab. 1, it can be seen that the daily maximum temperature in the first degree of the operation is $34,5^{\circ} \mathrm{C}$, while in the fourth operating degree temperature is $98,6^{\circ} \mathrm{C}$. The measured minimum temperatures were 10,4 ${ }^{\circ} \mathrm{C}$. According to [19] the atmospheric temperature on the day of measurement ranged between $7-12{ }^{\circ} \mathrm{C}$, an average of $9,5{ }^{\circ} \mathrm{C}$. It follows that the minimum temperature is almost atmospheric.

Table 1 Descriptive statistics of the first stage of measurement

\begin{tabular}{|c|c|c|}
\hline I. stage & $T_{1} /{ }^{\circ} \mathrm{C}$ & $T_{2} /{ }^{\circ} \mathrm{C}$ \\
\hline$\overline{\mathrm{X}}$ & 17,52 & 24,99 \\
\hline$T_{\max }$ & 34,50 & 98,60 \\
\hline$T_{\min }$ & 10,40 & 10,40 \\
\hline$\sigma$ & 7,77 & 21,61 \\
\hline$\sigma^{2}$ & 60,36 & 466,75 \\
\hline
\end{tabular}

In the second stage of the research, the temperature $\left(T_{2}\right)$ was measured at the most critical place of the compressor, which is under pressure at about 300 bar in the fourth degree of operation and the room temperature $\left(T_{1}\right)$. The external atmospheric temperature was also considered [19]. The total results obtained are given in Tab. 2. The $t$ test confirmed that there is no statistically significant difference in the minimum and maximum temperatures by the days of measurement.

Table 2 Descriptive statistics of the second stage of measurement

\begin{tabular}{|c|c|c|}
\hline II. stage & $T_{1} /{ }^{\circ} \mathrm{C}$ & $T_{2} /{ }^{\circ} \mathrm{C}$ \\
\hline$\overline{\mathrm{x}}$ & 27,19 & 33,86 \\
\hline$T_{\max }$ & 43,90 & 102,90 \\
\hline$T_{\min }$ & 19,50 & 21,10 \\
\hline$\sigma$ & 3,68 & 13,59 \\
\hline$\sigma^{2}$ & 13,56 & 184,61 \\
\hline
\end{tabular}

In the third stage of the research, a fan was added as a cooling system for the compressor station. The measurements were performed in the same way as in the second stage of the research. From Tab. 3 it can be seen that the average maximum temperature in the fourth degree of operation was $66,5^{\circ} \mathrm{C}$, which is $35,4 \%$ lower maximum temperature compared to the average maximum temperature without an added fan. 


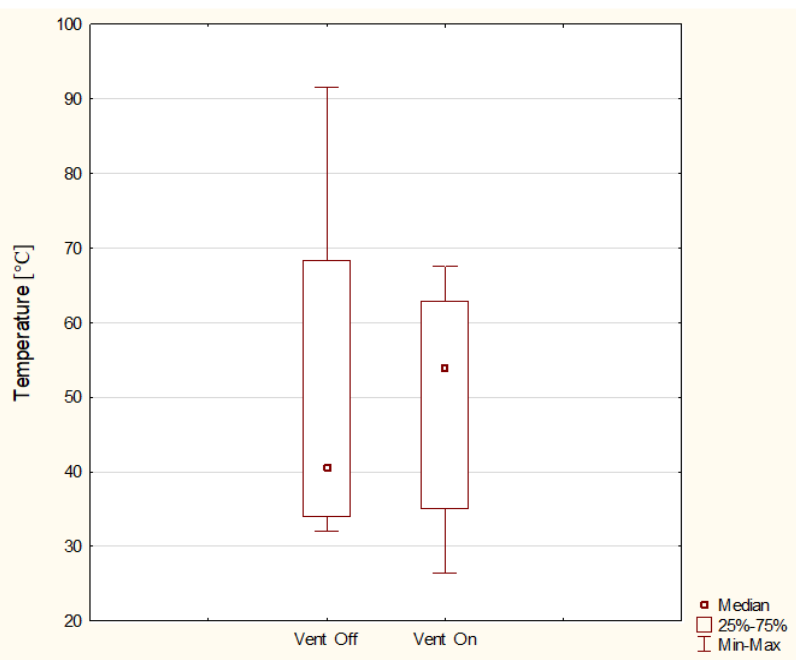

Figure 3 Box diagram of temperatures when the fan is on/off

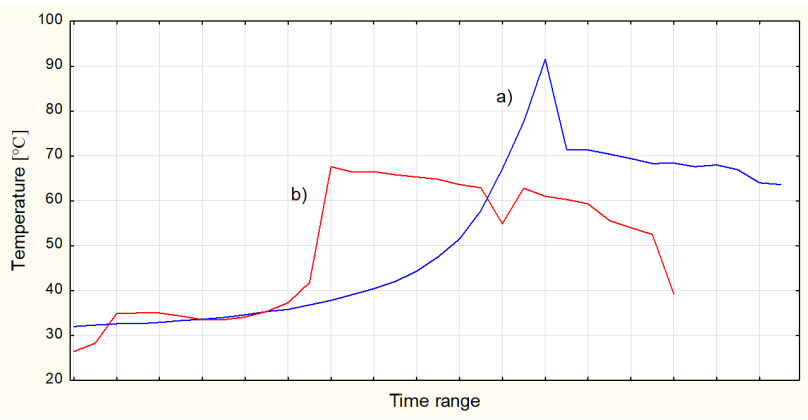

Figure 4 The difference in temperature on the compressor when a) the fan is turned off, and $b$ ) the fan is turned on

The average minimum temperature is almost identical to the average atmospheric temperature according to [19].

Table 3 Descriptive statistics of the third stage of measurement

\begin{tabular}{|c|c|c|}
\hline III. stage & $T_{1} /{ }^{\circ} \mathrm{C}$ & $T_{2} /{ }^{\circ} \mathrm{C}$ \\
\hline$\overline{\mathrm{x}}$ & 34,95 & 48,41 \\
\hline$T_{\max }$ & 40 & 66,50 \\
\hline$T_{\min }$ & 26,10 & 26,40 \\
\hline$\sigma$ & 3,8 & 14,01 \\
\hline$\sigma^{2}$ & 14,47 & 196,18 \\
\hline
\end{tabular}

In each day of measurement, the starting temperatures of the compressor are nearly identical to the atmospheric air temperature. Minimum temperatures in the lower quartile in Fig. 3 show a lower initial temperature value when the fan is on due to atmospheric air temperature.

Differences in temperature on the compressor when the fan is turned on and turned off are shown in Fig. 4.

When the compressor is on, its average operating time is 1 hour and 12 minutes. From the moment the compressor reaches the top value of temperature, it takes an average of 1 hour and 21 minutes until it cools down. It follows that the cooling time of the compressor is $58,33 \%$ faster when the compressor station has an added fan cooling system. The compressor is considered as cooled down when the difference between the compressor temperature and the atmospheric temperature does not exceed $5{ }^{\circ} \mathrm{C}$.

\section{SYSTEM OPTIMIZATION USING A NEURAL NETWORK}

Adding a fan in the existing system (Fig. 8) provides the optimal temperature of the compressor. The fan is controlled by a neural network. The default ratio of $70 \%$ $15 \%-15 \%$ in the MATLAB ${ }^{\circledR}[20]$ software package was used for learning, validation, and testing of the neural network. Fig. 5 shows the results obtained in the process of learning the neural network.


Out of a total of 40280 measured data, 7120 data (1780 logs) were measured in the first stage of measurement, 32740 data (8185 logs) were measured in the second stage and 420 data $(105 \operatorname{logs})$ were measured in the third stage.

Fig. 6 shows a neural network with input and output parameters, where:

$T_{\min }$ Minimum temperatures per day of measurement,

$T_{\max }$ Maximum temperatures per day of measurement,

$T_{1}$ Room temperature,

$T_{2}$ The temperature of the compressor,

$t_{p}$ Average compressor operating time per measurement day,

$T_{p r}$ The predictive temperature of the compressor.

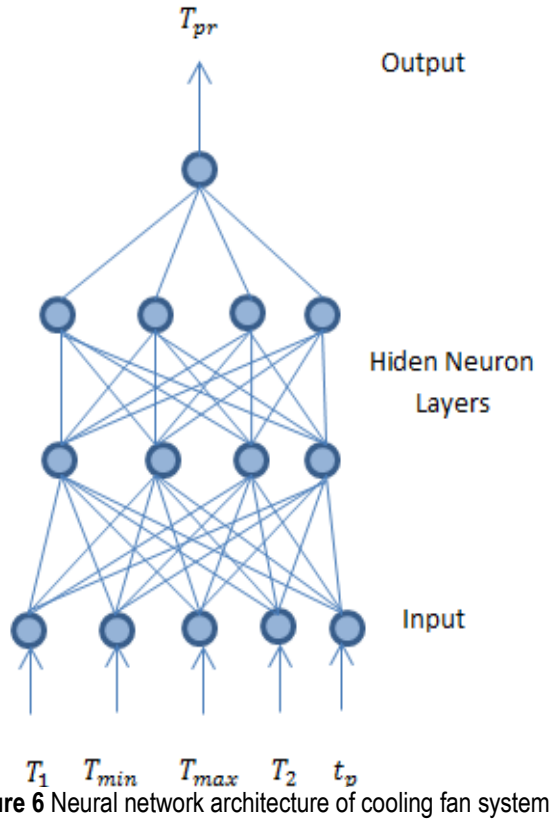

A device [16] controlled by the neural network performs measurements of engine temperature, ambient 
room temperature, and controls the operation of the engine and cooling system. The control device sends the measured data to the IoT user system with a graphical display at a remote location. In this way, in addition to the control component, a real-time monitoring system component is obtained. In the observed system, the control unit switches on the cooling system when the engine temperature reaches more than $60^{\circ} \mathrm{C}$ and switches it off when the temperature is lower than $40{ }^{\circ} \mathrm{C}$. If the temperature reaches a critical value set at $110^{\circ} \mathrm{C}$, the control unit switches off the engine until the cooling system cools it down to $80{ }^{\circ} \mathrm{C}$. The model of the observed system is given in Fig. 7. The actual appearance of the compressor station and system with the addition of a fan is shown in Fig. 8.

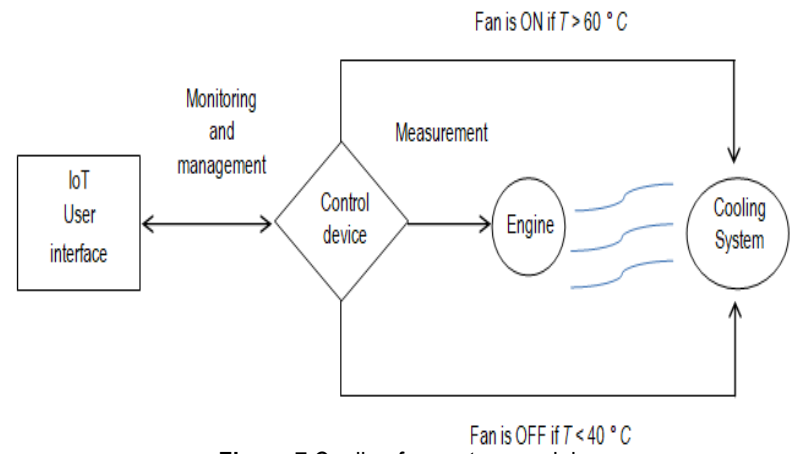

Figure 7 Cooling fan system model

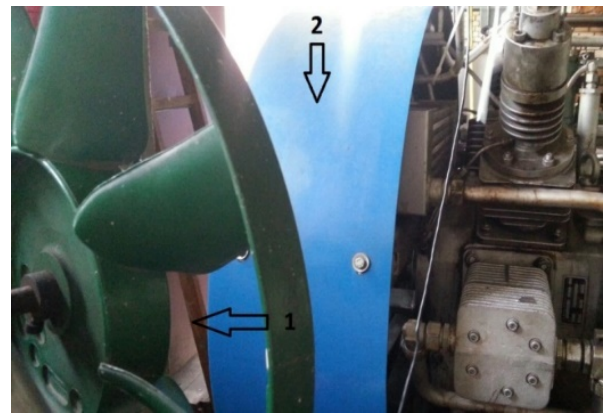

Figure 8 Added fan (1) as the cooling system on the compressor station (2)

The neural network was constructed as a MultipleLayerPerceptron (MLP) according to [21-26]. Two hidden layers were used because increasing the number of hidden layers did not yield better results. The error histogram for 9965 logs is shown in Fig. 9. The errors between the data used for training, validation and model testing are at $\varepsilon=0,001$. The minimum acceptable prediction accuracy of this model is $90 \%$.

The authors of [27-30] were using the Root Mean Square Error (RMSE) as a criterion for evaluating the model. The disadvantage of quality measures used by squaring the individual error due to which higher values of individual error take a larger share in the overall results and thus give greater importance to greater deviations [31]. Šarić et al., [32] used a neural network in the Maintenance Planning of Metallurgical Equipment. By further optimizing their model, RMSE takes on values averaging $3,7 \%$.

For validation of the model shown in Fig. 10 RMSE is $6,455 \%$. Since RMSE depends on the range of variable value according to P. Matic [31], it is important to note that the database used to train, validate, and test this neural network has big jumps in temperature values resulting in a large RMSE percentage. Although this result is acceptable, in further research it is necessary to use a larger number of samples because in this way the neural network would recognize a pattern of repetition of such outlying temperature values. Also, the results would certainly improve by using big data analysis, adding additional variables, considering age of the device.

The $R$ factor did not change significantly and it ranged from 0,81 to 0,87 . A graphical representation of the linear regression is shown in Fig. 11.
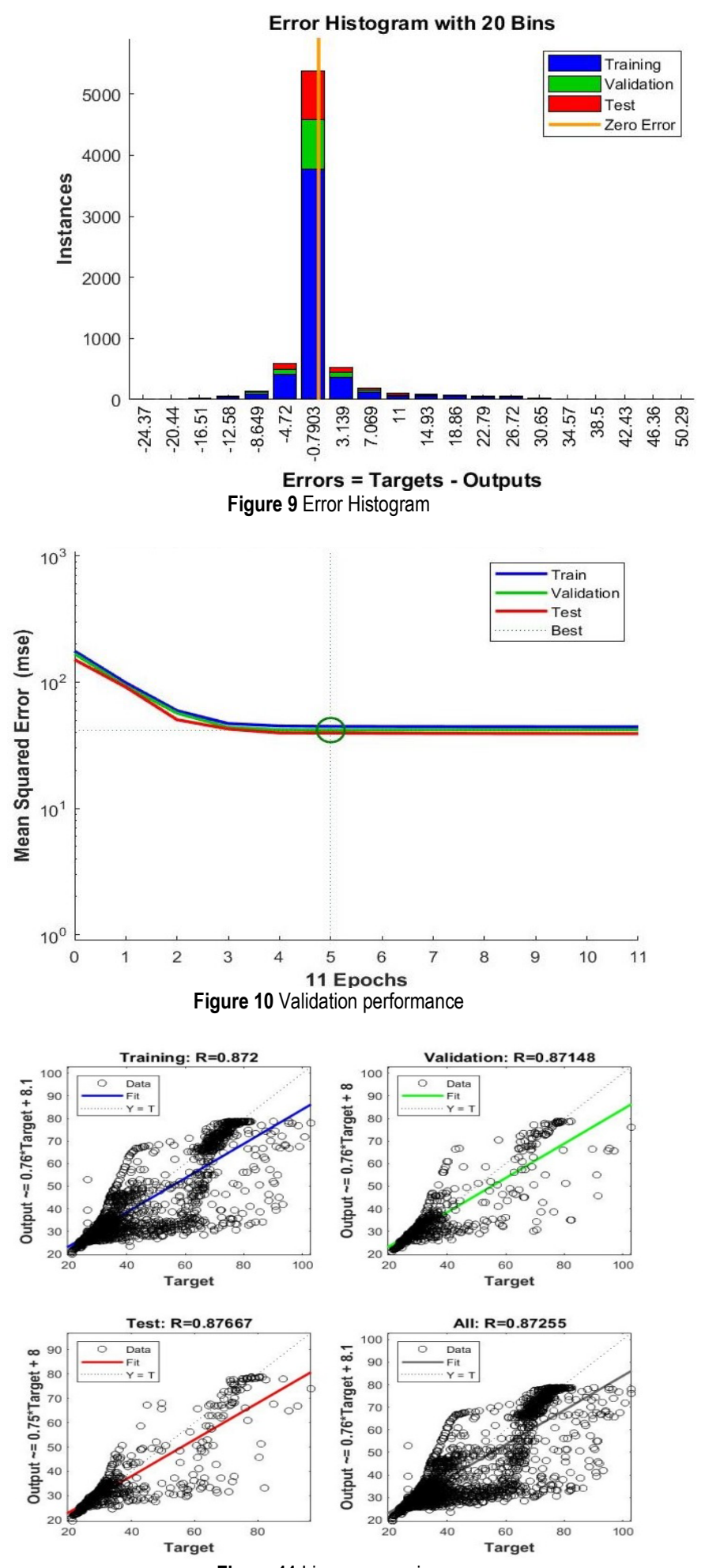

Figure 11 Linear regression 


\section{CONCLUSION}

In addition to turning the fan on and off, this neural network has other tasks. Those tasks are:

- collecting measured temperatures in real time,

- recognizing the temperature pattern on the compressor,

- $\quad$ predicting the temperature on the compressor,

- turning off the compressor if the temperature rises after turning the fan on,

- $\quad$ sending feedback to the system user (operator) through a web interface or SMS in real-time (system monitoring),

- alerting the users in the room where the system is located with an alarm sound signalling the case of failure or when the temperature reaches $10 \%$ higher temperature than the critical value,

- sending SMS to the operator when an alarm with predefined relevant data (eg. temperature value) is activated.

With the proposed system, the maximum average engine temperature is $35,4 \%$ lower than the average maximum temperature without an added fan. Compressor cooling time is $58,33 \%$ faster when the compressor station has an added fan cooling system.

RMSE of $6,455 \%$ implies further optimization of the proposed model by using some other new variables in future research. Based on absolute quality measures, it is not possible to set general limits (acceptable and unacceptable) of the prediction accuracy and make a model classification, so relative quality measures should be used for this purpose [31]. Extended measurements on all four operation degrees of the compressor in future research are proposed.

\section{ACKNOWLEDGMENTS}

I would like to thank the firm CONSTRUO-MAT d.o.o, the owners of the patent called Telematiks who allowed me to use their device for measurements. I would also like to thank the ĐĐ "Aparati" d.o.o group for enabling me to conduct research within their production hall.

\section{REFERENCES}

[1] Kozarac, D. (2008). Višezonski model izgaranja u HCCImotoru primjenom kemijske kinetike, Doktorski rad, Zagreb.

[2] Qi, X., Chen, G., Li, Y., Cheng, X., \& Li, C. (2019). Applying Neural-Network-Based Machine Learning to Additive Manufacturing: Current Applications, Challenges, and Future Perspectives. Engineering, 5(2019), 721-729. https://doi.org/10.1016/j.eng.2019.04.012

[3] Quantrille, T. E. \& Iiu, Y. A. (1991). Chapter 10 Introduction to Artificial Intelligence. Artificial Intelligence in Chemical Engineering, 197-231. https://doi.org/10.1016/B978-0-08-057121-8.50016-6

[4] Savkovic, B., Kovac, P., Rodic, D., Strbac, B., \& Klancnik, S. (2020). Comparison of artificial neural network, fuzzy logic and genetic algorithm for cutting temperature and surface roughness prediction during the face milling process, Advances in Production Engineering \& Management, 15(2), 137-150. https://doi.org/10.14743/apem2020.2.354

[5] Zhang, Z., Guan, Z. L., Zhang, J., \& Xie, X. (2019). A Novel Job-Shop Scheduling Strategy Based on Particle Swarm
Optimization and Neural Network. International Journal of Simulation Modelling, 18(4), 699-707. https://doi.org/10.2507/IJSIMM18(4)CO18

[6] Zhang, Z.L., Wang, Y.F., \& Li, Y. (2019). Inventory control model based on multi-attribute material classification: An integrated grey-rough set and probabilistic neural network approach, Advances in Production Engineering \& Management, 14(1), 93-111. https://doi.org/10.14743/apem2019.1.314

[7] Galar, D. \& Kumar, U. (2017). Maintenance Decision Support Systems. eMaintenance, Chapter 7, 371-474. https://doi.org/10.1016/B978-0-12-811153-6.00007-5

[8] Stephanopoulos, G. (1990). Artificial Intelligence "What will its contribution be to process control?". Solutions to the Shell Standard Control Problem, 591-646. https://doi.org/10.1016/B978-0-409-90186-3.50029-X

[9] Chaudhuri, T., Soh, Y. C., Li, H., \& Xie, L. (2019). A feed forward neural network based in door-climate control framework for thermal comfort and energy saving in buildings. Aplied Energgy, 248, 44-53. https://doi.org/10.1016/j.apenergy.2019.04.065

[10] Reynolds, J., Ahmad, M. W., Rezgui, Y., \& Hippolyte, J. L. (2019). Operational supply and demand optimisation of a multi-vector district energy system using artificial neural networks and a genetic algorithm. Aplied Energy, 235, 699713. https://doi.org/10.1016/j.apenergy.2018.11.001

[11] Afram, A. \& Raahemifar, K. (2017). Artificial neural network (ANN) based model predictive control (MPC) and optimization of HVAC systems : A state of the art review and case study of a residental HVAC system. Energy an Buildings, 141, 96-113. https://doi.org/10.1016/j.enbuild.2017.02.012

[12] Noroozi, A., Mokhtari, H., \& Abadi, I. N. K. (2013). Research on computational intelligence algorithms with adaptive learning approach for scheduling problems with batch processing machines. Neurocomputing, 101, 190-203. https://doi.org/10.1016/j.neucom.2012.08.011

[13] Alphonsus, E. R. \& Abdullah, M. O. (2016). A review on the aplications of programmable logic controllers (PLCs). Renewable and Sustainable Energy Reviews, 60, 1185-1205. https://doi.org/10.1016/j.rser.2016.01.025

[14] Ahiska, R. \& Mamur, H. (2012). A test system and supervisory control and data acquisition application with programmable logic controller for thermoelectric generators. Energy Conversion and Management, 64, 15-22. https://doi.org/10.1016/j.enconman.2012.05.010

[15] Metzger, M. \& Laszczyk, P. (2004). Implementation of Predictive Model Based Control on Programmable Logic Controller. IFAC Proceedings Volumes, 37(13), 1341-1346. https://doi.org/10.1016/S1474-6670(17)31414-3

[16] Seehttps://worldwide.espacenet.com/publicationDetail $\mathrm{s} /$ biblio? $\mathrm{II}=0 \& \mathrm{ND}=3 \&$ adjacent $=$ true\&locale $=$ en_EP \&FT $=$ $\mathrm{D} \&$ date $=20161104 \& \mathrm{CC}=\mathrm{HR} \& \mathrm{NR}=\mathrm{P} 20150460 \overline{\mathrm{A}} 2 \& \mathrm{KC}=\mathrm{A}$ 2, 15.09.2019.

[17] Horenbeek, A. V. \& Pintelon, L. (2013). A dynamic predictive maintenance policy for complex multi-component systems. Reliability Engineering \& System Safety, 120, 3950. https://doi.org/10.1016/j.ress.2013.02.029

[18] Roupas, P. (2008). Predictive modelling of dairy manufacturing processes. International Dairy Journal, 18, (7), 741-753. https://doi.org/10.1016/j.idairyj.2008.03.009

[19] Seehttps://freemeteo.com.hr

[20] MATLAB R2018a (64-bit), licence No: 968398

[21] P. Matić, Predviđanje dotoka rijeke Cetine u akumulaciju Peruća pomoću umjetne neuronske mreže, Kvalifikacijski doktorski ispit, Split 2012.

[22] S. Lončarić, M. Subašić, Neuronske mreže: Duboke neuronske mreže i duboko učenje, FER Sveučilište u Zagrebu,https://www.fer.unizg.hr/_download/repository/de ep.pdf, 27.06.2020. 
[23] https://loomen.carnet.hr/pluginfile.php/56586/mod resource/content/0/P4_Neuronske.pdf, od 27.06.2020.

[24] https://repozitorij.efst.unist.hr/islandora/object/efst: 1847/preview, 27.06.2020. https://doi.org/10.1080/14432471.2020.1855778

[25] Seehttps://bib.irb.hr/datoteka/431844.Neuronske_mreze.pdf 27.06.2020.

[26] http://eris.foi.hr/11neuronske/nn-predavanje1.html, 27.06.2020.

[27] Šarić, T., Šimunović, G., Vukelić, Đ., Šimunović, K., \& Lujić, R. (2018). Estimation of CNC Grinding Process Parameters Using Different Neural Networks. Tehnički vjesnik, 25(6), 1770-1775. https://doi.org/10.17559/TV-20180419095119

[28] Šarić, T., Šimunović, G., Šimunović, K., \& Svalina, I. (2016). Estimation of Machining Time for CNC Manufacturing using Neural Computing. International journal of simulation modelling, 15(4), 663-675. https://doi.org/10.2507/IJSIMM15(4)7.359

[29] Šarić, T., Šimunović, G., Lujić, R., Šimunović, K., \& Antić, A. (2016). Use of Soft Computing Technique for Modelling and Prediction of CNC Grinding Process. Tehnički vjesnik, 23(4), 1123-1130. https://doi.org/10.17559/TV-20160405151333

[30] Šarić, T., Šimunović, G., Šimunović, K. (2013). Use of Neural Networks in Prediction and Simulation of Steel Surface Roughness. International journal of simulation modelling, 12(4); 225-236. https://doi.org/10.2507/IJSIMM12(4)2.241

[31] Matić, P. (2014). Kratkoročno predviđanje hidrološkog dotoka pomoću umjetne neuronske mreže. Doktorska disertacija, Sveučilište u Splitu, Fakultet Elektrotehnike, Strojarstva i Brodogradnje.

[32] Šarić, T., Lujić, R., Šimunović, G. (2005). Applying of Artifical Neutral Network in Maintenance Planning of Metallurgical Equioment. Metalurgija, 44(2), 107-112.

\section{Contact information:}

Ivan ĐURAČIÍ, PhD student

(Corresponding author)

University of Slavonski Brod,

Mechanical Engineering Faculty,

$\operatorname{Trg}$ I. B. Mazuranic 2, 35000 SlavonskiBrod, Croatia

E-mail: idjuracic@gmail.com

Marinko STOJKOV, $\mathrm{PhD}$

University of Slavonski Brod,

Mechanical Engineering Faculty,

$\operatorname{Trg}$ I. B. Mazuranic 2, 35000 SlavonskiBrod, Croatia

E-mail: mstojkov@unisb.hr

Tomislav ŠARIĆ, PhD

University of Slavonski Brod,

Mechanical Engineering Faculty,

Trg I. B. Mazuranic 2, 35000 SlavonskiBrod, Croatia

E-mail: tsaric@unisb.hr

Tomislav ALINJAK, PhD

HEP-ODS d.o.o. Zagreb,

Elektra Slavonski Brod,

P. Krešimira IV 11, 35000 SlavonskiBrod, Croatia

E-mail: tomislav.alinjak@hep.hr

Krešimir CRNOGORAC, ing. el.

CONSTRUO-MAT d.o.0.,

Trg Ignjata Alojza Brlića 4, Slavonski Brod, Croatia

E-mail: info@construomat.com 